\title{
11 . Passivity or protest? Understanding the dimensions of mobilization on rights to services in Khayelitsha, Cape Town
}

\author{
LISA THOMPSON AND NDODANA NLEYA
}

\section{Introduction}

Here in Khayelitsha, we often hold meetings and when government fails to respond to us we take further steps. I think meetings come up with good solutions. To protest is the best solution because our parents used to do that in the past and look, now we have a democratic country. (Interview respondent, Khayelitsha, 2007)

Protests around service delivery have been a source of discussion and debate in South Africa in recent years, following a series of demonstrations - some violent - over lack of housing, water and sanitation. This chapter examines how violent protest forms part of a continuum of participatory strategies used by the poor to claim their socio-economic rights. As the quotation above highlights, various methods of participation can be viewed as progressive steps on a ladder. Drawing on mobilization and social movement theories, we explore how resource-deprived communities weigh up the different forms of participatory involvement with the state that are available to them, and choose their course of action in trying to claim what they are entitled to but may not actually receive.

We examine the findings of a survey on perceptions of governance and service delivery, which was undertaken in 2007 in Khayelitsha, a poor township some $35 \mathrm{~km}$ from Cape Town. The survey was designed to obtain a comprehensive understanding of the diversity of participatory strategies employed by individuals and communities. Drawing on an eclectic mix of approaches, we argue that communities in Khayelitsha are highly aware of the political opportunities and the political opportunity structures available to them, and also of the relative power of protest action in yielding results from government. ${ }^{1}$ This chapter illustrates that, while mobilization and collective action form the loosest definition of social movement action (in the sense that street committees and other groupings come together as needed in order to act collectively), the range of actions is very carefully chosen, and protest is a means of last resort. 
The study shows that, throughout Khayelitsha, grassroots forms of political and social organization are part of daily life. Street committees - a form of organization with its origins in the struggle against apartheid - have been rejuvenated and are a key self-created or 'invented' space in which political and socio-economic rights and entitlements are discussed and in which decisions affecting the wider community are made. We are cognizant of the fact that, as Kabeer has pointed out, not all forms of associational politics are democratic. She reminds us that:

there is nothing inherently democratic about associations and not all groups promote democratic rights ... Equally, however, others can help expand the space available for democratic activity. These groups may not necessarily operate in the political sphere, but they become 'democratically relevant'. (2005: 35$)$

In the light of what has been said, it is worth remembering that at this stage little is known about how democratic the internal decisionmaking processes of the new-style street committees really are. It is clear that these forms of organization (and the platform for social movement activism they represent) provide a basis for challenging the state on rights and entitlement to basic services that have been promised but are not forthcoming (Thompson and Nleya, 2008).

'Thicker' forms of democracy - where civic engagement extends beyond voting - are not a given, but are something that emerges through contestation (Tapscott, 2007). To explore the forms of contestation that emerge in the light of the survey, the remainder of this chapter is divided into four sections. The first section examines some of the analytical and conceptual issues we have used to frame the study. The next section describes the study area and the methodology of the study. The third section focuses specifically on some of the main findings of the study in relation to three areas: community concerns about service delivery, perceptions of institutional democratic practices and participatory strategies for approaching issues of community concern. The final section brings together the findings and draws some conclusions.

\section{Understanding mobilization strategies in Khayelitsha: analytical considerations}

Since the adoption of a liberal democratic form of government in 1994, the evolution of state-society relations in South Africa has been closely observed by academics, policy think tanks, development agencies and the local and international press. One view is that the 'marginalized' poor (or 'underclass') have still not bought into the liberal notions of citizen- 
ship that are embodied in current institutional manifestations of liberal democracy. Tapscott (2005) attributes this to the top-down governance processes driven by the ruling classes and state bureaucrats. Others argue that the poor are variously perceived as apathetic and reluctant to take advantage of the fresh opportunities available to them, especially now that apartheid has gone (Thompson and Matheza, 2005). Meanwhile, the violent forms of protest that break out sporadically around lack of service delivery have caught both academic and media attention (Ballard et al., 2006). Our survey findings indicate that, while everyday forms of community expression are mostly ignored by the media, this does not mean that they are not at the heart of any conception of democracy. As Bracking states:

the chronically poor express agency, notably through informal selforganization, religious organizations, clientelism, populism, authoritarianism, insurrection, criminality, and war ... Then, while the poor are performing live, unnoticed, at another venue, they are identified as 'failing' to act in accordance with a script which expects them to 'join in' the structures of the relatively privileged (feeding elite prejudice that the poor are 'not trying enough'). The result is an unrealistic, judgemental and ultimately disempowering expectation of how the poor should behave. (2005: 1014)

By arguing that the poor fail to participate in the new 'participatory state', proponents of a virtuous notion of citizenship in the civic republican tradition (Hill, 1994; Kofman, 1995) provide a restricted vision of how the poor should act. The language they employ is illustrated by Leslie Sklair's definition of active citizenship:

The good democratic citizen is a political agent who takes part regularly in politics ... Active citizens keep informed and speak out against public measures that they regard as unjust ... Although they do not refrain from pursuing their own and their reference group's interests, they try to weigh the claims of other people impartially ... They are public meeting-goers and joiners of voluntary organizations. (Cited in Hadenius, 2001: 17)

It is clear that perceptions of the 'active citizen' derived from this tradition create a view of the 'poor' that is both static and idealized. MacKian (1995) also cautions against over-romanticization of active citizenship, for, as well as seeking the positive effects of citizen action, so-called 'active citizens' are often on the look-out for positions of influence for themselves. We argue instead that there is a range of mobilization 